\title{
Comparison of non-tracer and tracer methods for determination of volatile fatty acid production rate in the rumen of sheep fed on two levels of intake
}

\author{
Cécile Martin ${ }^{1}$, Niels B. Kristensen ${ }^{2}$ and Pekka Huhtanen ${ }^{3}$ \\ ${ }^{1}$ Unité de Recherche sur les Herbivores, INRA Theix, 63122 Saint-Genès-Champanelle, France \\ ${ }^{2}$ Department of Animal Nutrition and Physiology, Danish Institute of Agricultural Sciences, Box 50, DK-8830 Tjele, Denmark \\ ${ }^{3}$ Animal Production Research, Agricultural Research Centre, FIN-31600 Jokioinen, Finland
}

(Received 9 October 2000 - Revised 19 February 2001 - Accepted 19 March 2001)

\begin{abstract}
The aim of the present work was to estimate volatile fatty acid (VFA) production rate in the rumen of sheep fed two levels of intake using both a tracer (TM; by isotope dilution) and a nontracer method (NTM; by supplementary infusion) in steady-state conditions. Six wethers received a diet containing $700 \mathrm{~g}$ lucerne hay and $300 \mathrm{~g}$ ground maize/ $\mathrm{kg}$ in eight equal meals at $3 \mathrm{~h}$ intervals per $\mathrm{d}$. The diet $(9.8 \mathrm{MJ}$ metabolizable energy (ME)/kg DM) was offered at $90 \% \mathrm{ad}$ libitum consumption (high intake, HI) or $45 \%$ ad libitum consumption (low intake, LI) in a $2 \times 2$ crossover design. Each sheep received five intrarumen VFA solutions infused continuously for $24 \mathrm{~h}$ at rates of $250 \mathrm{ml}$ and $165 \mathrm{ml} / \mathrm{h}$ for the $\mathrm{HI}$ and LI respectively. The first infusion, considered as a control treatment $(\mathrm{Con})$, consisted of a solution of $\left[1-{ }^{13} \mathrm{C}\right]$ propionate $(7 \mathrm{mmol} / \mathrm{d})$. The four other solutions were isoenergetic (1.9 MJ ME/kg DM intake) mixtures of unlabelled propionate $\left(\mathrm{C}_{3}\right)$ and butyrate $\left(\mathrm{C}_{4}\right)$ at different levels: $0.90 \mathrm{~mol} \mathrm{C}_{4} / \mathrm{kg} \mathrm{DM}$ intake; $0.60 \mathrm{~mol} \mathrm{C}_{4}+0.45 \mathrm{~mol}$ $\mathrm{C}_{3} / \mathrm{kg}$ DM intake; $0.30 \mathrm{~mol} \mathrm{C}_{4}+0.90 \mathrm{~mol} \mathrm{C}_{3} / \mathrm{kg}$ DM intake; $1.35 \mathrm{~mol} \mathrm{C}_{3} / \mathrm{kg} \mathrm{DM}$ intake. The VFA infusions did not affect rumen fermentation of the basal diet $(\mathrm{pH}$, osmotic pressure, protozoa numbers), and comparable DM digestibility of the diet among the different treatments was observed. Both estimation methods demonstrated a similar increase (1.7-fold) in the rumen VFA production rate of sheep fed at intakes varying between 0.9 to 1.7 times maintenance. Irrespective of the intake level, the rumen production rate of individual VFA was on average 1.5-fold higher when estimated by the TM compared with the NTM. Rumen VFA production rates estimated by the NTM and TM represented $80 \%$ and $120 \%$ ME intake respectively. The difference between NTM and TM estimates seems likely to be caused mainly by overestimation of the VFA production rates by the TM.
\end{abstract}

Rumen: Volatile fatty acids: Production rate: Intake level

Volatile fatty acids (VFA) are the main energy source for ruminants, contributing 50-80\% of the total energy supply (Thomas \& Clapperton, 1972; Sutton, 1985). The major part (75\%) of the rumen VFA disappears across the reticulorumen wall with a variable absorption rate, especially when concentrate diets are fed. This means that the rumen VFA concentration is not directly proportional to their production rate (Esdale et al. 1968; Sharp et al. 1982). Assessment of the quantitative contribution of VFA to ruminant nutrition requires measurements of the VFA production rate in the rumen. In general, two groups of techniques are employed for in vivo determination of rumen VFA production rates: tracer methods (TM) and non-tracer methods (NTM). TM usually use an isotope-dilution technique of a solution of VFA labelled with radioactive isotopes $\left({ }^{14} \mathrm{C},{ }^{3} \mathrm{H}\right)$ and continuously infused into the rumen at a constant rate (Leng \& Leonard, 1965; Leng \& Brett, 1966; Bruce et al. 1987). The radioactivity of these compounds has been considered to be a major disadvantage of in vivo experiments and Breves et al. (1987) proposed the use of a stable isotope $\left({ }^{13} \mathrm{C}\right)$. A variety of NTM is used to quantify VFA production rate in the rumen, including $\mathrm{CH}_{4}$ production, portal-arterial difference, and perturbation of the steady state. $\mathrm{CH}_{4}$ production is an index of rumen

\footnotetext{
Abbreviations: HI, high intake level; LI, low intake level; ME, metabolizable energy; NTM, non-tracer method; OM, organic matter; TM, tracer method; VFA, volatile fatty acid.

* Corresponding author: Dr Cécile Martin, fax +33 4736242 73, email cecile@clermont.inra.fr
} 
fermentation used to obtain indirect estimates of VFA production. The portal-arterial difference in VFA concentration precludes accurate estimation of rumen VFA production, because metabolism of VFA in the rumen wall is not considered. The perturbation of steady state method relies on changes in VFA rumen concentration when one or a mixture of acids is infused at a constant rate in steady-state conditions (Bath et al. 1962; France \& Siddons, 1993). More recently, Huhtanen \& Jaakkola (1995) suggested a technique with increasing levels (at least three) of VFA infusion into the rumen. Rumen VFA production rate can then be estimated using a regression approach. This estimation is based on the assumptions that there is an equilibrium between rumen concentration and rate of absorption, and that the infusions do not alter the rumen fermentation pattern and digestion of the diet.

Since no direct simultaneous comparison of different techniques appears to have been published, comparison of the results obtained using these different methods is hampered by differences in the experimental conditions (animals, diets, level of intake, type of isotope). Moreover, most of the studies on the estimation of VFA production rates aimed to improve the precision of the technique, while the main factors affecting the rumen production rate (intake level, nature of the diet) have received little attention (Leng \& Brett, 1966; Esdale et al. 1968; Bauman et al. 1971). Thus, the aim of the present study was to estimate VFA production rates in the rumen of sheep fed two levels of intake, and to define more clearly the utilization limits of the TM and NTM for in vivo estimation of rumen VFA production rates.

\section{Materials and methods}

\section{Animals, feeding and experimental procedures}

Texel wethers ( $n$ 6, 2 years old) with an average body weight 73.2 (SD 2.8) kg at the start of the experiment and $73 \cdot 3$ (SD 5.5) kg body weight at the end of the experiment were used. The animals were fitted with a rumen cannula (i.d. $60 \mathrm{~mm}$ ) made of polyamide and polyvinyl chloride (Synthesia, Nogent sur Marne, France). Surgery was performed under general anaesthesia (Halothane; ICI Pharma-veterinaire, Paris, France). The sheep were allowed 4 weeks to recover after surgery. During the experiment, the sheep received a diet containing $700 \mathrm{~g}$ chopped lucerne hay ( $914 \mathrm{~g}$ organic matter $(\mathrm{OM}), 144 \mathrm{~g}$ crude protein and $571 \mathrm{~g}$ neutral detergent fibre $/ \mathrm{kg} \mathrm{DM} / \mathrm{kg}$ and $300 \mathrm{~g}$ ground maize (988 g OM, $91 \mathrm{~g}$ crude protein and $131 \mathrm{~g}$ neutral detergent fibre $/ \mathrm{kg} \mathrm{DM}) / \mathrm{kg}$ in eight equal meals at $3 \mathrm{~h}$ intervals per $\mathrm{d}$ with an automatic feeder throughout the experiment. The diet supplied 9.80 MJ metabolizable energy (ME)/kg DM intake and was offered at 1550 (SD 75) g DM, corresponding to $90 \%$ ad libitum consumption (high intake, HI), or at 810 (SD 5) g DM, corresponding to $45 \%$ ad libitum consumption (low intake, LI). The animals were allocated to two groups (three sheep in each group) and to the two levels of DM intake according to a crossover design, whereby both of the two levels of DM intake were fed to all six sheep.

The animals were housed individually in metabolism cages in a room with continuous lighting and air conditioning, and had free access to lick mineralized salt blocks. The sheep did not have free access to water. Instead, water was continuously infused into the rumen, using a sixchannel peristaltic pump (Minipuls; Gilson, Villers le Bel, France), in amounts corresponding to the average daily ad libitum consumption determined during the adaptation period using a water meter. Continuous intrarumen infusion of water and distribution of feed at short intervals were chosen as optimal steady state conditions in the rumen to avoid random variations in microbial fermentation, liquid pool size and consequently VFA concentrations. The experiment consisted of two periods. Each period lasted 6 weeks, comprising a 3 -week adaptation period followed by a 3-week measurement period.

\section{Volatile fatty acid infusions}

Each sheep received five VFA solutions infused continuously into the rumen using a peristaltic pump. Each infusion lasted $24 \mathrm{~h}$ and the total volume infused was the same as the average water intake during the adaptation period (i.e. 6 litres/d and 4 litres/d for the HI and LI respectively). The first infusion consisted of a solution of $\left[1-{ }^{13} \mathrm{C}\right]$ propionate $\left(0.525 \mathrm{~g} / \mathrm{d}\right.$, i.e. $0.007 \mathrm{~mol}\left[1-{ }^{13} \mathrm{C}\right]$ propionate/d, $99.9 \%$ enriched; Leman, St Quentin en Yvelines, France). Since exchange of propionic acid $\mathrm{C}$ with other short-chain fatty acids is quantitatively insignificant (Peters et al. 1990), $\left[{ }^{13} \mathrm{C}\right]$-propionate was chosen as the reference to predict the in vivo production rate of all VFA. Considering the negligible amounts of $\left[1-{ }^{13} \mathrm{C}\right]$ propionate infused, the first infusion was also considered as a control treatment (Con). The four other solutions infused were made of four mixtures of non-labelled propionate $\left(\mathrm{C}_{3}\right)$ and butyrate $\left(\mathrm{C}_{4}\right)$ at different levels: $0.90 \mathrm{~mol} \mathrm{C}_{4} / \mathrm{kg}$ DM intake (B); $0.60 \mathrm{~mol}$ $\mathrm{C}_{4}+0.45 \mathrm{~mol} \mathrm{C} \mathrm{C}_{3} / \mathrm{kg}$ DM intake (Bp); $0.30 \mathrm{~mol} \mathrm{C}_{4}+$ $0.90 \mathrm{~mol} \mathrm{C}_{3} / \mathrm{kg} \mathrm{DM}$ intake (bP); $1.35 \mathrm{~mol} \mathrm{C}_{3} / \mathrm{kg} \mathrm{DM}$ intake (P). These solutions were chosen to be isoenergetic $(1.9 \mathrm{MJ}$ $\mathrm{ME} / \mathrm{kg} \mathrm{DM}$ intake), to avoid appetite depression, and to ensure sufficient increment in their rumen concentrations to be detected by GC. The $\mathrm{pH}$ of all VFA solutions was adjusted to $\mathrm{pH} 6.0$ with $10 \mathrm{M}-\mathrm{NaOH}$. This $\mathrm{pH}$ was chosen to be close to the rumen $\mathrm{pH}$ measured during the adaptation period to the diet. The effective amounts and composition of the VFA solutions infused are given in Table 1, and the design of infusions was as follows: Con, from 16.00 hours on day 4 to 16.00 hours on day 5 of week 1 ; B, from 16.00 hours on day 1 to 16.00 hours on day 2 of week 2 ; Bp, from 16.00 hours on day 4 to 16.00 hours on day 5 of week 2 ; bP, from 16.00 hours on day 1 to 16.00 hours on day 2 of week 3; P, from 16.00 hours on day 4 to 16.00 hours on day 5 of week 3 .

\section{Sampling procedures and measurements}

Rumen liquid samples $(100 \mathrm{ml})$ were taken from the dorsal, ventral and cranial sacs of the rumen via the cannula using a suction pump and a rigid plastic tube (length $400 \mathrm{~mm}$; i.d. $15 \mathrm{~mm}$ ), and then filtered with a $250 \mu \mathrm{m}$ nylon filter.

Just before the onset of VFA infusions, samples of rumen liquid were withdrawn from each animal and used as blanks for ${ }^{13} \mathrm{C}$ and $\mathrm{Cr}$-EDTA analyses. 
Table 1. Characteristics of infused volatile fatty acid solutions

\begin{tabular}{|c|c|c|c|c|c|c|c|c|c|c|}
\hline \multirow[b]{2}{*}{ Infusion... } & \multicolumn{5}{|c|}{ High intake level } & \multicolumn{5}{|c|}{ Low intake level } \\
\hline & Con & $\mathrm{B}$ & $\mathrm{Bp}$ & $b P$ & $P$ & Con & $\mathrm{B}$ & $\mathrm{Bp}$ & $b P$ & $P$ \\
\hline Water (litres/d) & $5 \cdot 90$ & 6.05 & 6.06 & $6 \cdot 36$ & $6 \cdot 64$ & $4 \cdot 01$ & $4 \cdot 13$ & $4 \cdot 21$ & $4 \cdot 22$ & 4.47 \\
\hline$\left[1-{ }^{13} \mathrm{C}\right]$ propionate $(\mathrm{mol} / \mathrm{d})$ & 0.007 & - & - & - & - & 0.007 & - & - & - & - \\
\hline Propionate $(\mathrm{mol} / \mathrm{d})$ & - & - & 0.64 & $1 \cdot 30$ & $2 \cdot 17$ & - & - & 0.32 & 0.66 & 1.40 \\
\hline Butyrate $(\mathrm{mol} / \mathrm{d})$ & - & $1 \cdot 18$ & 0.90 & 0.46 & - & - & 0.66 & 0.44 & 0.24 & - \\
\hline Metabolizable energy $(\mathrm{MJ} / \mathrm{d})$ & - & $2 \cdot 72$ & 3.05 & 3.05 & $3 \cdot 31$ & - & 1.53 & 1.50 & 1.56 & $2 \cdot 15$ \\
\hline
\end{tabular}

Con, $0.007 \mathrm{~mol} / \mathrm{d}\left[1-{ }^{13} \mathrm{C}\right]$ propionate; $\mathrm{B}, 0.90 \mathrm{~mol}$ butyrate $/ \mathrm{kg} \mathrm{DM}$ intake; $\mathrm{Bp}, 0.60 \mathrm{~mol}$ butyrate $+0.45 \mathrm{~mol}$ propionate $/ \mathrm{kg} \mathrm{DM}$ intake; bP, $0.30 \mathrm{~mol}$ butyrate $+0.90 \mathrm{~mol}$ propionate $/ \mathrm{kg}$ DM intake; $\mathrm{P}, 1.35 \mathrm{~mol}$ propionate $/ \mathrm{kg} \mathrm{DM}$ intake.

The $\mathrm{pH}$ of the rumen liquid was measured immediately on six samples taken $16 \cdot 5,18 \cdot 0,19 \cdot 5,21 \cdot 0,22 \cdot 5$ and $24 \cdot 0 \mathrm{~h}$ after the start of each infusion using a digital $\mathrm{pH}$-meter (CG840, $\mathrm{Ag}-\mathrm{AgCl}$ electrode; Schott Geräte, Hofheim, Germany). These sampling times were chosen in order to have three samples at feeding times and the three others between two meals. A $10 \mathrm{ml}$ portion $(2 \times 5 \mathrm{ml})$ from each sample of rumen fluid was mixed with 0.1 volume orthophosphoric acid $(10 \mathrm{ml} / \mathrm{l})$ and frozen $\left(-20^{\circ} \mathrm{C}\right)$ before VFA analysis by GC using 4-methylvaleric acid as internal standard (Jouany, 1982). For the control treatment (Con), two more $5 \mathrm{ml}$ portions were preserved as described earlier and used to determine the ${ }^{13} \mathrm{C}$ enrichment of rumen propionate using 2-chloroethylesters of propionate by $\mathrm{GC}-$ isotope ratio MS (Kristensen, 2000). A portion of $8 \mathrm{ml}$ was also frozen $\left(-20^{\circ} \mathrm{C}\right)$ for osmotic pressure measurements made with a vapour pressure osmometer (KNAUER D1000, Berlin, Germany) on particle-free rumen fluid obtained by centrifugation at $20000 \mathrm{~g}$ for $10 \mathrm{~min}$ at $4^{\circ} \mathrm{C}$. Protozoa were counted in samples collected $22.5 \mathrm{~h}$ after the start of infusions. For this, $1 \mathrm{ml}$ rumen fluid was preserved at $4^{\circ} \mathrm{C}$ with $3 \mathrm{ml}$ preservative solution (glycerol-formaldehydedistilled water (50:2:48, by vol.)). Protozoa were counted using a Dolfuss cell (Elvetec Services, Clermont-Ferrand, France) according to the procedure described by Jouany \& Senaud (1982). The volume and turnover rate of the rumen liquid phase was determined from a pulse dose of Cr-EDTA solution (140 mg Cr in $50 \mathrm{ml}$ water), prepared according to the procedure of Binnerts et al. (1968), and injected into the rumen of each sheep via the cannula just before the beginning of each VFA infusion. Rumen liquid samples were taken and filtered as described previously, just before infusion and $3 \cdot 0,4 \cdot 5,6 \cdot 0,7 \cdot 5,13 \cdot 5,16 \cdot 5,19 \cdot 5$ and $22 \cdot 5 \mathrm{~h}$ after the beginning of the infusion, and $20 \mathrm{ml}$ liquid were frozen $\left(-20^{\circ} \mathrm{C}\right)$ until analysed. The $\mathrm{Cr}$ content of samples was determined by atomic absorption spectrometer (PerkinElmer 2380; Perkin-Elmer Bois d'Arcy, France) after centrifugation of samples at $5000 \mathrm{~g}$ for $15 \mathrm{~min}$ at $4^{\circ} \mathrm{C}$.

Feed intake and refusals were measured and recorded daily during the experimental period to calculate DM intake. Total tract digestibility was determined from daily total collection of faeces during all the 3-week infusion periods and each week corresponded to the following combinations: Con (control treatment), $\mathrm{B}$ and $\mathrm{Bp}$ (the highest butyrate:propionate ratio infused), $\mathrm{bP}$ and $\mathrm{P}$ (the highest propionate:butyrate ratio infused). Faeces were weighed and mixed before sampling a $50 \%$ aliquot for each sheep. After DM determination $\left(80^{\circ} \mathrm{C}\right.$ for $\left.48 \mathrm{~h}\right)$, faecal samples were pooled for each week and each sheep. The chemical composition of experimental feeds and faecal samples was determined according to Association of Analytical Chemists procedures (Association of Analytical Chemists, 1990). Gross energy of alfalfa hay and maize was obtained from Institut National de la Recherche Agronomique feed tables (Institut National de la Recherche Agronomique, 1989) and the ME of the diet was calculated from the equations of Andrieu \& Demarquilly (1987).

\section{Calculations and statistical analyses}

The volume and the turnover rate of the rumen liquid phase were calculated from the exponential decrease of $\mathrm{Cr}$ concentrations with time. After semi-logarithmic linefitting, the slope represented the fluid dilution rate $(/ \mathrm{h})$, and the volume of liquid phase in the rumen was calculated from the intercept at $t 0$.

For the TM, the rumen production rate of propionate $(\mathrm{mol} / \mathrm{d})$ was calculated using steady-state tracer dilution kinetics of the $\left[1-{ }^{13} \mathrm{C}\right]$ propionate. The $\mathrm{C}$ flux through the rumen propionate pool is measured and then divided by three to obtain the rumen propionate flux according to the following equation:

$$
\begin{aligned}
& \text { (AF infusate }-\mathrm{AF} \text { background }) \times \mathrm{IR} /((\mathrm{AF} \text { rumen } \\
& \quad-\mathrm{AF} \text { background }) \times 3),
\end{aligned}
$$

where IR is the infusion rate of $\left[1-{ }^{13} \mathrm{C}\right]$ propionate solution $(\mathrm{mol} / \mathrm{d})$, and $\mathrm{AF}$ corresponds to the atomic fraction of ${ }^{13} \mathrm{C}={ }^{13} \mathrm{C} /\left({ }^{12} \mathrm{C}+{ }^{13} \mathrm{C}\right)$ for the infused $\left[1-{ }^{13} \mathrm{C}\right]$ propionate solution ( $\mathrm{AF}$ infusate), for the rumen samples before (AF background) and during infusion at equilibrium (AF rumen).

For the NTM, the regression approach of Huhtanen \& Jaakkola (1995) adapted from Bath et al. (1962) was used to estimate the propionate and butyrate production rates by dividing the intercept $\mathrm{a}$ by the slope $\mathrm{b}$ of the regression:

$$
y=\mathrm{a}+b x
$$

where $y$ is the concentration $(\mathrm{mmol} / \mathrm{l})$ or molar proportion (\%) of propionate or butyrate present in the rumen liquid, and $x$ is the amount of propionate or butyrate infused $(\mathrm{mol} / \mathrm{d})$. The slope of the regression equations obtained between concentration and proportion of propionate or butyrate and their infusion rate were tested by analysis of covariance.

For both methods, production rates of other individual 
VFA $\left(\mathrm{VFA}_{\mathrm{i}}\right)$ were respectively obtained by multiplying the propionate (or butyrate) production rate by the $\mathrm{VFA}_{\mathrm{i}}$ : propionate (or butyrate) concentration ratio.

Data were analysed by ANOVA with the following factors: period, animal, infusion, intake level and the interaction infusion $\times$ intake level. For each animal, values for $\mathrm{pH}$, osmotic pressure, individual and total VFA concentrations, ${ }^{13} \mathrm{C}$-enrichment of rumen propionate within a treatment were the mean values for the different sampling times $(n$ 6). The effect of the nature of VFA infused for the NTM $\left(C_{3} v \cdot C_{4}\right)$ and the effect of the method (NTM $v$. TM) to estimate the rumen VFA production rate were tested by ANOVA with period, sheep, intake level, method, method nested within VFA infusion nature, and the interaction methodXintake level. The relation between the production rate of propionate estimated by the NTM and TM was tested by a covariance analysis including TM, intake level and the interaction TMXintake level as cofactors. Data were statistically analysed using the GLM procedure of SAS (SAS/STAT ${ }^{\circledR}$ User's Guide, Release 6.03, 1988; Statistical Analysis Systems Institute Inc., Cary, NC, USA). Differences were tested using the Duncan's test and declared significant at $P<0.05$.

\section{Results \\ Rumen variables and digestibility}

On average, for the 3 weeks of measurements, the DM digestibilities of the diet were 67.2 (SD 0.5) and 69.5 (SD $1.8) \%$ respectively, for animals fed the HI and LI $(P>$ 0.05). Comparable DM digestibilities of the diet were observed with the control treatment (Con) for the HI $(67.6 \%)$ and LI (67.9\%). No effect of the infused mixtures of unlabelled propionate and butyrate was observed on the digestibilities of the diet for the two intake levels $(P>$ 0.05 ), although the VFA infusions richest in butyrate (B and $\mathrm{Bp})$ tended to increase DM digestibility $(71.4 \%)$ compared with the other infusions for animals fed at LI.

The protozoal number in the rumen was higher $(P<0.001$; Table 2$)$ for animals fed at $\mathrm{HI}$ than those fed at $\mathrm{LI}\left(387 \times 10^{3} / \mathrm{ml}\right.$ v. $223 \times 10^{3} / \mathrm{ml}$ on average respectively), and the proportion of Entodinium (mean value $72 v$. $79 \%, P<0.01$ ), Epidinium (mean value 20 v. $13 \%$, $P<0.01$ ) and Dasytricha (mean value 0.4 v. $0.8 \%$, $P<0.05$ ) differed between HI and LI. Irrespective of the intake level, the number and the composition of the protozoal population was unaffected by the different VFA infusions $(P>0.05$; Table 2$)$.

The rumen $\mathrm{pH}$ values were significantly $(P<0.001)$ lower for $\mathrm{HI}$ than for the LI (mean value 6.44 v. 6.58, Table $3)$. Infusions of VFA increased the rumen $\mathrm{pH}(P<0.001)$ in the same way for the two levels of intake (infusionXintake level interaction $P>0.05$ ), i.e. an increase of $0.25 \mathrm{pH}$ units for $\mathrm{HI}$ and $0.22 \mathrm{pH}$ units for LI. The osmotic presure was higher $(P<0.001)$ for HI than for LI (mean value $302 v$. $244 \mathrm{mosmol} / \mathrm{l} \mathrm{respectively)} \mathrm{and} \mathrm{the} \mathrm{effect} \mathrm{observed} \mathrm{for} \mathrm{VFA}$ infusions on the rumen osmotic pressure was different for the two levels of intake (infusion Xintake level interaction $P<0 \cdot 001$, Table 3). For HI, rumen osmotic pressure increased by $92 \mathrm{mosmol} / \mathrm{l}$ between treatments Con and $\mathrm{Bp}$ 
(248 to 340 mosmol/l) and then decreased to $301 \mathrm{mosmol} / \mathrm{l}$. For LI, the osmotic pressure increased by $37 \mathrm{mosmol} / \mathrm{l}$ between infusions Con and Bp (216 to $253 \mathrm{mosmol} / \mathrm{l})$ and then stayed stable with the infusions highest in propionate $(\mathrm{bP}, \mathrm{P})$. The mean volumes of the rumen liquid phase were 6.5 litres and 5.9 litres for the $\mathrm{HI}$ and LI respectively $(P<$ $0.001)$ and were not affected by treatments $(P>0.05$, Table 3), although the rumen liquid volume tended to increase with the highest infusion of propionate (infusion $\mathrm{P}$ ) at HI. Liquid dilution rate was higher $(P<0.001)$ for $\mathrm{HI}$ (mean value $0 \cdot 117 / \mathrm{h}$ ) than for LI (mean value $0 \cdot 070 / \mathrm{h}$ ) and decreased as propionate increased in VFA infusions $(P<$ $0 \cdot 05$ ) for animals fed at HI. No effect of VFA infusion was observed on the rumen fluid dilution rate for LI (Table 3).

The rumen concentrations of individual VFA for the different treatments are presented in Table 3 . The rumen concentrations of the total and individual VFA (except for isovalerate) were higher for animals receiving the basal diet (Con) at HI compared with LI. Conversely, the molar proportions of the individual VFA characterizing the basal diet were comparable between the two levels of intake (mean value $63.5 \%$ for acetate, $19.1 \%$ for propionate, and $13.6 \%$ for butyrate) except for the two isoacids for which the molar proportions were lower when animals were fed at HI compared with LI (results not shown). Compared with the control treatment (Con), the rumen concentration of all VFA (except acetate) was changed $(P<0.001)$ by infusion of unlabelled acids in the same way for the two intake levels (infusion $\times$ intake level interaction $P>0.05$ ). Considering only the four unlabelled VFA infusions, the response to gradual replacement of butyrate with propionate in VFA infusions was a decrease in rumen butyrate concentrations $(P<0.001)$ and an increase in rumen propionate concentrations $(P<0 \cdot 001)$, whereas the rumen concentrations of acetate were not changed $(P>0 \cdot 05)$. For the rumen concentration of total VFA, we observed similar concentrations for treatments $\mathrm{B}, \mathrm{Bp}$, and $\mathrm{bP}$, but an increase with the highest infusion level of propionate $(\mathrm{P})$, and thus for the two intake levels.

The regression equations calculated for the amount of unlabelled acids infused $(\mathrm{mol} / \mathrm{d})$ and their rumen concentration $(\mathrm{mmol} / \mathrm{l})$ or molar proportion $(\%)$ are presented in Table 4. Irrespective of the intake level, the slopes of the regression equations obtained from the concentration and molar proportion were comparable for the butyrate $(P>$ $0.05)$, but lower for the propionate $(P<0.01$ and $P<0.05$ for the HI and LI respectively) when estimated from proportions instead of from concentrations. This latter observation suggested an increase in the absorption rate of propionate with the highest infusion rate of propionate (treatment P). The quantity of propionate infused with infusion $\mathrm{P}$ was considerable and corresponded to $1.4 \mathrm{~mol}$ $\mathrm{C}_{3} / \mathrm{kg} \mathrm{DM}$ intake or $22 \% \mathrm{ME}$ intake for $\mathrm{HI}$ and $1.7 \mathrm{~mol}$ $\mathrm{C}_{3} / \mathrm{kg} \mathrm{DM}$ intake or $27 \% \mathrm{ME}$ intake for LI. So, the regression equations were recalculated without results from the infusion $\mathrm{P}$ and the comparable slope of the new regression equations (Table 4) confirmed our hypothesis. According to these results, modifications in the rumen conditions may occur for a quantity of propionate infused exceeding $1 \mathrm{~mol} / \mathrm{kg}$ DM intake or $20 \% \mathrm{ME}$ intake. Moreover, variations in VFA concentrations may result 
Table 4. Variables of the regression equations between the rumen concentration or molar proportion of propionate or butyrate and their infusion rate*

(Mean values with their standard errors for six sheep)

\begin{tabular}{|c|c|c|c|c|c|c|c|c|c|c|c|c|}
\hline & \multicolumn{6}{|c|}{ High intake level } & \multicolumn{6}{|c|}{ Low intake level } \\
\hline & \multirow{2}{*}{$\begin{array}{l}\text { Infusion rate } \\
(\mathrm{mol} / \mathrm{d})\end{array}$} & \multicolumn{2}{|c|}{ Intercept } & \multicolumn{2}{|c|}{ Slope } & \multirow[b]{2}{*}{$R$} & \multirow{2}{*}{$\begin{array}{l}\text { Infusion rate } \\
(\mathrm{mol} / \mathrm{d})\end{array}$} & \multicolumn{2}{|c|}{ Intercept } & \multicolumn{2}{|c|}{ Slope } & \multirow[b]{2}{*}{$R$} \\
\hline & & Mean & SE & Mean & SE & & & Mean & SE & Mean & SE & \\
\hline \multicolumn{13}{|c|}{ From infusions Con, $\mathrm{B}, \mathrm{Bp}, \mathrm{bP}, \mathrm{P}+$} \\
\hline Propionate (mM) & $0-2 \cdot 17$ & $19 \cdot 5$ & 1.3 & $12 \cdot 3$ & $1 \cdot 1$ & 0.90 & $0-1.40$ & $14 \cdot 3$ & 0.5 & $15 \cdot 5$ & 0.8 & 0.97 \\
\hline Propionate $(\mathrm{mol} / 100 \mathrm{~mol})$ & $0-2 \cdot 17$ & $17 \cdot 7$ & 0.7 & $7 \cdot 7$ & 0.5 & 0.94 & $0-1.40$ & $17 \cdot 2$ & 0.5 & $13 \cdot 7$ & 0.7 & 0.96 \\
\hline Butyrate $(\mathrm{mM})$ & $0-1 \cdot 18$ & $15 \cdot 2$ & 0.9 & $12 \cdot 6$ & $1 \cdot 3$ & 0.87 & $0-0.66$ & $9 \cdot 8$ & 0.5 & $14 \cdot 7$ & 1.3 & 0.90 \\
\hline Butyrate $(\mathrm{mol} / 100 \mathrm{~mol})$ & $0-1.18$ & $12 \cdot 8$ & 0.7 & 9.7 & 1.0 & 0.88 & $0-0.66$ & 11.5 & 0.6 & $15 \cdot 3$ & 1.5 & 0.89 \\
\hline \multicolumn{13}{|c|}{ From infusions Con, B, Bp, bP† } \\
\hline Propionate (mM) & $0-1.30$ & $20 \cdot 3$ & 0.6 & $10 \cdot 2$ & 0.9 & 0.92 & $0-0.66$ & $14 \cdot 2$ & 0.6 & $16 \cdot 4$ & 1.6 & 0.91 \\
\hline Propionate $(\mathrm{mol} / 100 \mathrm{~mol})$ & $0-1 \cdot 30$ & $17 \cdot 6$ & 0.9 & 8.2 & 0.7 & 0.90 & $0-0.66$ & $16 \cdot 7$ & 0.6 & $16 \cdot 5$ & 1.5 & 0.92 \\
\hline
\end{tabular}

${ }^{*}$ For details of diets and procedures, see p. 332.

† Con, $0.007 \mathrm{~mol} / \mathrm{d}\left[1{ }^{13} \mathrm{C}\right]$ propionate; B, $0.90 \mathrm{~mol}$ butyrate $/ \mathrm{kg} \mathrm{DM}$ intake; $\mathrm{Bp}, 0.60 \mathrm{~mol}$ butyrate $+0.45 \mathrm{~mol}$ propionate/kg DM intake; bP, $0.30 \mathrm{~mol}$ butyrate + $0.90 \mathrm{~mol}$ propionate $/ \mathrm{kg}$ DM intake; P, $1.35 \mathrm{~mol}$ propionate $/ \mathrm{kg}$ DM intake (for details, see Table 1).

from sampling or differences in the rumen fluid volume, as observed more particularly for animals fed at HI, whereas VFA molar proportions take these different aspects into account. Consequently, the individual regression equations for the following estimations of VFA production rates were calculated, for the two intake levels, from VFA proportions with the first four infusions (Con, B, Bp and bP) for the propionate, and with all the infusions (Con, $\mathrm{B}, \mathrm{Bp}, \mathrm{bP}$ and $\mathrm{P}$ ) for the butyrate.

\section{Estimation of volatile fatty acid production rates by the non- tracer and tracer method}

Estimations of the rumen production rates of the different VFA from the propionate and butyrate with the NTM were comparable within the same intake level $\left(\mathrm{C}_{3} v . \mathrm{C}_{4}, P>\right.$ 0.05 , Table 5). However, the rumen production of the individual VFA differed between the two methods tested (NTM $v$. TM, $P<0 \cdot 001$, Table 5), irrespective of the intake level considered (methodxintake level interaction, NS). Values were on average 1.5-fold higher when estimated

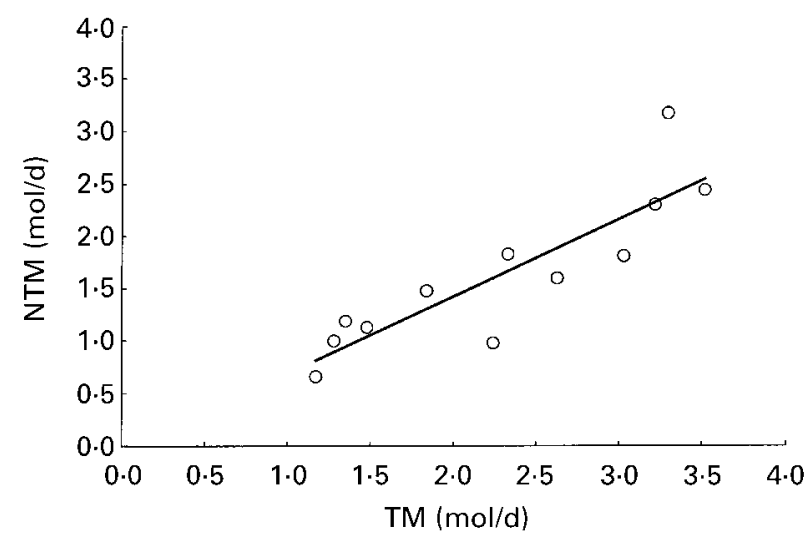

Fig. 1. Relationship $(P<0.05)$ between the non-tracer method (NTM) and tracer method (TM) for determination of propionate production rate in the rumen of sheep $(n 12)$ fed two intake levels. For details of diets, infusions and procedures, see Table 1 and p. 332. $\mathrm{NTM}=0.74$ TM (SE 0.131) -0.047 (SE 0.319), $R 0.870$. by the TM compared with the NTM. The correlation $(P<0.05)$ between the two techniques for the estimation of the rumen propionate production rate was: $\mathrm{NTM}=0.74$ TM (SE 0.13) - 0.047 (SE 0·319), r 0.87 (Fig. 1). Regardless of the VFA considered and estimation method, the rumen VFA production rates, expressed in $\mathrm{mol} / \mathrm{d}$, differed between the two intake levels $(P<0.001$, Table 5). The rumen production rate of total VFA was on average 1.7-fold higher for animals fed at HI (1550 g DM intake) than for those fed at LI (810 g DM intake). Rumen VFA production rate/kg DM intake was slightly higher for LI than HI, but the difference was not significant $(P>0 \cdot 05)$.

\section{Discussion}

Effect of volatile fatty acid infusions on rumen variables and digestibility

The main assumptions common for both the tracer and nontracer techniques for in vivo estimation of VFA production rates are that they cause no modifications of the rumen characteristics or of the microbial ecosystem, in order to avoid any disturbance in fermentation of the basal diet. In our study, unlabelled VFA infusions compared with the basal diet (Con) slightly decreased the liquid dilution rate for animals at HI, and increased both the rumen osmotic pressure, although values remained in the physiological range (Rémond et al. 1995), and the rumen $\mathrm{pH}$. Addition of $\mathrm{NaOH}$ in the VFA solutions infused to adjust their $\mathrm{pH}$ to $6 \cdot 0$ might explain this effect of the rumen $\mathrm{pH}$. Huhtanen et al. (1993) and Miettinen \& Huhtanen (1996) did not find a significant effect of the VFA infusions on the rumen $\mathrm{pH}$. However, in their experiments, the quantities of VFA infused were smaller compared with those used in the present trial $(0.75 v .1 .35 \mathrm{~mol}$ propionate $/ \mathrm{kg}$ DM intake $)$, the $\mathrm{pH}$ of solutions was adjusted to only 4, which required relatively lower amounts of $\mathrm{NaOH}$, and no treatment in which no VFA solution was infused (corresponding in our present study to the treatment Con) was included in their experimentation. It can be concluded that infusions of VFA did not involve significant changes in the microbial 
ecosystem since the population of protozoa remains constant between treatments. It would appear, therefore, that the amount of VFA infused in our study had only minor effects on the rumen fermentation of the basal diet, and the comparable DM digestibility of the diet between treatments supported this conclusion.

\section{Intake level}

Irrespective of the estimation method and the VFA considered, the rumen total VFA production rate, expressed in $\mathrm{mol} / \mathrm{d}$, differed between the two intake levels, and was on average 1.7-fold higher when animals ingested 1.9-fold more feed. To our knowledge, no results are available in the literature about the effect of intake level on direct estimation of in vivo VFA production rate in the rumen. VFA production rates in the rumen of sheep have been estimated from rumen VFA concentration (Leng, 1970). Using the same equation, the total VFA production rate increased between HI and LI, although this difference was lower (1.4-fold) than found in our present study (1.7-fold). The rumen total VFA production rates, expressed per $\mathrm{kg}$ DM intake, were comparable between the two intake levels. This suggested that the rumen production of VFA was proportional to the amount of OM digested in the rumen. Hence, in the following discussion, results on the rumen VFA production rates will be expressed per $\mathrm{kg}$ DM intake and pooled over the two intake levels.

\section{Volatile fatty acid production rate by the non-tracer method}

Both estimation methods for the rumen VFA production rate were based on the assumption that molar proportions in the rumen represent ratios in production and thus that absorption rates of the different VFA were similar. One advantage of the NTM was that replacing butyrate infusion with propionate gave information on absorption rates of the different VFA. The rumen production rates of the individual VFA calculated from the propionate and butyrate with the NTM were comparable within the same intake level. This suggested similar fractional absorption rates between the different VFA and was in agreement with other results (Kristensen et al. 1996; Nozière et al. 2000). In addition, Dijkstra et al. (1993) observed equal rumen disappearance rates for acetate, propionate and butyrate at rumen $\mathrm{pH}$ in the region of 7, close to those (6.5) measured in our study.

The mean rumen production rates of acetate, propionate and butyrate with the NTM were $4.3,1.3$ and $0.9 \mathrm{~mol} / \mathrm{kg}$ DM intake respectively. Assuming that OM digestibility in the total tract is $2 \%$ higher than DM digestibility, and that OM apparently digested in the rumen is 0.75 , we calculated the quantity of acetate, propionate and butyrate produced in the rumen using the stoichiometric principle (Demeyer, 1991). Values obtained were $3 \cdot 5,1 \cdot 1$, and $0.8 \mathrm{~mol} / \mathrm{kg} \mathrm{DM}$ intake for acetate, propionate and butyrate respectively and were close to those obtained in our study. Calculated as the sum of acetate, propionate and butyrate production rates, the total rumen VFA production rate in the rumen was $6.5 \mathrm{~mol} / \mathrm{kg} \mathrm{DM}$ intake and equivalent to $7.8 \mathrm{MJ} \mathrm{ME} / \mathrm{kg}$ DM intake. Compared with the ME ingested ( $9.8 \mathrm{MJ} \mathrm{ME} / \mathrm{kg}$ DM intake), the rumen VFA production corresponded in our 
Table 6. Reported total volatile fatty acid production rates estimated by the isotope dilution technique for different animal species given various diets

\begin{tabular}{|c|c|c|c|c|c|}
\hline \multirow[b]{2}{*}{ References } & \multicolumn{3}{|c|}{ Experiment characteristics } & \multicolumn{2}{|c|}{$\begin{array}{l}\text { Total volatile fatty acid } \\
\text { production rate }\end{array}$} \\
\hline & Animal & Diet & Method & $\begin{array}{c}\mathrm{mol} / \mathrm{kg} \\
\text { DM intake }\end{array}$ & $\begin{array}{c}\text { mol/kg digestible } \\
\text { organic matter } \\
\text { intake }\end{array}$ \\
\hline Bergman et al. (1965) & Sheep & Grass & ${ }^{14} \mathrm{C}_{4}$ infusion & $7 \cdot 8$ & $10 \cdot 5$ \\
\hline Leng \& Leonard (1965) & Sheep & Lucerne & ${ }^{14} \mathrm{C}_{2,3,4}$ infusion & $10 \cdot 3$ & $19 \cdot 1$ \\
\hline \multirow[t]{4}{*}{ Leng \& Brett (1966) } & Sheep & Lucerne & ${ }^{14} C_{2,3,4}$ infusion & $10 \cdot 3$ & $19 \cdot 8$ \\
\hline & Sheep & Lucerne-maize (25:75, w/w) & ${ }^{14} \mathrm{C}_{2,3,4}$ infusion & $10 \cdot 1$ & $13 \cdot 6$ \\
\hline & Sheep & Lucerne-maize (50:50, w/w) & ${ }^{14} C_{2,3,4}$ infusion & $6 \cdot 8$ & $10 \cdot 1$ \\
\hline & Sheep & Lucerne-straw (10:90, w/w) & ${ }^{14} C_{2,3,4}$ infusion & $3 \cdot 0$ & $7 \cdot 5$ \\
\hline Weller et al. (1967) & Sheep & Hay & ${ }^{14} \mathrm{C}_{2,3,4}$ infusion & $5 \cdot 5$ & $11 \cdot 7$ \\
\hline Nozière et al. (2000) & Sheep & Hay & ${ }^{13} \mathrm{C}_{3}$ infusion & $6 \cdot 1$ & $10 \cdot 4$ \\
\hline \multirow[t]{2}{*}{ Esdale et al. (1968) } & Dry cow & Lucerne & ${ }^{14} C_{2,3,4}$ infusion & $7 \cdot 6$ & $14 \cdot 9$ \\
\hline & Dry cow & Maize silage & ${ }^{14} C_{2,3,4}$ infusion & $7 \cdot 9$ & $11 \cdot 8$ \\
\hline \multirow[t]{3}{*}{ Oshio et al. (1977) } & Heifer & Hay-concentrate $(60: 40$, w/w) & ${ }^{14} \mathrm{C}_{2}$ pulse dose & $4 \cdot 4$ & $6 \cdot 8$ \\
\hline & Heifer & Hay-concentrate $(70: 30, w / w)$ & ${ }^{14} \mathrm{C}_{2}$ pulse dose & $5 \cdot 3$ & $8 \cdot 5$ \\
\hline & Heifer & Concentrate & ${ }^{14} \mathrm{C}_{2}$ pulse dose & $4 \cdot 8$ & 5.9 \\
\hline \multirow[t]{2}{*}{ Sharp et al. (1982) } & Steer & Hay-whole maize $(16: 84$, w/w) & ${ }^{14} \mathrm{C}_{2,3,4}$ infusion & $9 \cdot 2$ & $13 \cdot 9$ \\
\hline & Steer & Hay-ground maize (16:84, w/w) & ${ }^{14} \mathrm{C}_{2,3,4}$ infusion & $7 \cdot 1$ & $10 \cdot 8$ \\
\hline \multirow[t]{2}{*}{ Siciliano-Jones \& Murphy (1989) } & Steer & Hay-concentrate $(80: 20$, w/w) & ${ }^{14} \mathrm{C}_{2,3,4}$ infusion & $7 \cdot 0$ & $12 \cdot 1$ \\
\hline & Steer & Hay-concentrate $(20: 80, w / w)$ & ${ }^{14} \mathrm{C}_{2,3,4}$ infusion & $6 \cdot 9$ & $9 \cdot 1$ \\
\hline
\end{tabular}

present study to $79 \% \mathrm{ME}$ intake and appeared to be a reasonable estimate, even probably slightly overestimated compared with values $(65-75 \%$ total $\mathrm{ME})$ reported by Bergman (1990) in his review. Hogan \& Weston (1967) reported a close linear relationship between OM digested and total VFA rumen production rate in sheep fed ad libitum, with a slope of $9 \cdot 2 \mathrm{~mol} \mathrm{VFA} / \mathrm{kg}$ OM digested. This value was similar to that measured in the present study (10.0 mol VFA produced/kg OM digested).

\section{Volatile fatty acid production rate by the tracer method}

With the TM, the total VFA production rate (sum of acetate, propionate and butyrate production rates) averaged $9.8 \mathrm{~mol} / \mathrm{kg} \mathrm{DM}$ intake. In the literature, the total VFA production rate obtained by the isotope-dilution technique was on average $7 \cdot 1 \mathrm{~mol} / \mathrm{kg} \mathrm{DM}$ intake, but the range of variation was high and values varied from 3.0 to $10 \cdot 3 \mathrm{~mol} / \mathrm{kg}$ DM intake (Table 6). To take into account variations due to the nature of the diet, we expressed our results and those of the literature per $\mathrm{kg}$ of digestible OM intake. In our experiment, total VFA production rates were $15.6 \mathrm{~mol} / \mathrm{kg}$ digestible OM intake and were included in the range of total VFA production rates observed in the literature (from 5.9 to $19.8 \mathrm{~mol} / \mathrm{kg}$ digestible OM intake, Table 6). In terms of ME, estimated rumen VFA production was equivalent to $11.8 \mathrm{MJ} \mathrm{ME} / \mathrm{kg} \mathrm{DM}$ intake and represented $120 \%$ total $\mathrm{ME}$ intake, suggesting an overestimation of the rumen VFA production rate with the TM.

The rumen production rate of individual VFA was on average 1.5-fold higher when estimated by the TM compared with the NTM. Only one other direct comparison between these two techniques for measuring the VFA production rate can be found in the literature (Nozière et al. 2000). In that study, ewes were fed a low level of intake (500 g DM intake), and the higher rumen propionate production rate $(1 \cdot 5$-fold) with the TM compared with the NTM was similar to our results (1.5-fold). An eventual interconversion of the labelled propionate to the other VFA may explain the discrepancy between the two estimation methods for rumen VFA production rate, but this does not agree with the literature (Bruce et al. 1987; Peters et al. 1990), stating that the exchange of propionic acid $\mathrm{C}$ with other VFA is quantitatively insignificant. A possible sequestration of VFA by the rumen micro-organisms for biosynthesis, which may cause overestimation of the VFA production rates with the TM, has been suggested (Kristensen \& Danfaer, 2000), but this has never been quantified in vivo for propionate. Concerning the metabolism of acetate by rumen micro-organisms, quantitative estimates made in vitro (Emmanuel et al. 1974) and in vivo (NB Kristensen, personal communication) indicated that only $3 \%$ and $8 \%$ of the labelled acetate $\mathrm{C}$ were incorporated into the microbial biomass respectively. Thus, the more probable reason for the overestimation of VFA production rates with the TM may be related to the position of the labelled $\mathrm{C}$ on the propionate $\left(\left[1-{ }^{13} \mathrm{C}\right]\right.$ propionate). Indeed, in his review Sutton (1985) reported problems of overestimation of propionic acid production when $\left[1-{ }^{14} \mathrm{C}\right]$ propionate was used rather than $\left[2-{ }^{14} \mathrm{C}\right]$ propionate due to the labile nature of the carboxyl-C transformed into ${ }^{14} \mathrm{CO}_{2}$ in the rumen.

Irrespective of the method used, a comparable effect of intake level on the rumen VFA production rate was observed. The production of VFA in the rumen increased proportionally $(1 \cdot 7$-fold) to the amount of OM ingested by the sheep for intakes increasing to $0.9-1.7$ times maintenance. According to the accuracy of techniques (for the propionate, SE $0.42 \mathrm{~mol} / \mathrm{d}$ for both methods), the TM and NTM are suitable to show differences in VFA production rates between diets characterized by very different $\mathrm{OM}$ digestibility. This variability in the measurements with the 
different methodologies might make more difficult statistical comparisons for intermediates diets.

The two techniques tested provide different rumen VFA production rate estimations. According to ME intake, rumen VFA production rates with the NTM appeared reasonable, but the NTM requires at least three rates of VFA infusion, which makes it laborious. On the other hand, the TM appears easier to apply and the small quantity of labelled VFA infused limits risks of unphysiological situations. However, the TM seemed to overestimate the rumen VFA production rate. The potential reasons for this overestimation with the TM were proposed and are being investigated in further studies.

\section{Acknowledgements}

This work was carried out at INRA-Theix (France) with the help of D. Djouvinov. The authors wish to thank M. Fabre for animal care, help with sampling and protozoa counting, Y. Rochette for analyses, P. Nozière for helpful discussions and $\mathrm{B}$. Michalet-Doreau for her precious advice during the drafting of the manuscript.

\section{References}

Andrieu J \& Demarquilly C (1987) Alimentation des ruminants: révision des systèmes et des tables de l'INRA (Ruminant alimentation: revision of INRA systems and tables). Bulletin Technique du CRZV Theix, INRA 70, 61-73.

Association of Analytical Chemists (1990) Official Methods of Analysis, 15th ed., Arlington, VA: AOAC.

Bauman DE, Davis CL \& Bucholtz HF (1971) Propionate production in the rumen of cows fed either a control or highgrain, low-fibre diet. Journal of Dairy Science 54, 1282-1287.

Bath IH, Balch CC \& Rook AJF (1962) A technique for the estimation of the ruminal production of volatile fatty acids in the cow. Proceedings of the Nutrition Society 21, 9-10.

Bergman EN (1990) Energy contributions of volatile fatty acids from the gastrointestinal tract in various species. Physiological Reviews 70, 567-589.

Bergman EN, Reid RS, Murray MG, Brockway JM \& Whitelaw FG (1965) Interconversions and production of volatile fatty acids in the sheep rumen. Biochemical Journal 97, 53-58.

Binnerts WT, Van't Klooster ATh \& Frens AM (1968) Soluble chromium indicator measured by atomic absorption in digestion experiments. Veterinary Record 82, 470.

Breves G, Schulze E, Sallmann HP \& Höller H (1987) Sodium $\left[1-{ }^{13} \mathrm{C}\right]$ acetate as a label for measuring acetate production rate in the rumen of sheep. Journal of Veterinary Medicine 34, 698-702.

Bruce LA, Lobley GE \& MacRae JC (1987) Measurement of volatile fatty acid production rates in sheep given roughage. Research Veterinary Science 42, 47-52.

Demeyer DI (1991) Quantitative aspects of microbial metabolism in the rumen and hindgut. In Rumen Microbial Metabolism and Ruminant Digestion, pp. 217-237 [JP Jouany, editor]. Paris: INRA Editions.

Dijkstra J, Boer H, Van Bruchem J, Bruining M \& Tamminga S (1993) Absorption of volatile fatty acids from the rumen of lactating dairy cows as influenced by volatile fatty acids concentration, $\mathrm{pH}$ and rumen liquid volume. British Journal of Nutrition 69, 385-396.

Emmanuel B, Milligan LP \& Turner BV (1974) The metabolism of acetate by rumen microorganisms. Canadian Journal of Microbiology 20, 183-185.
Esdale WJ, Broderick GA \& Satter LD (1968) Measurement of ruminal volatile fatty acid production from alfalfa hay or corn silage rations using a continuous infusion isotope dilution technique. Journal of Dairy Science 51, 1823-1830.

France J \& Siddons RC (1993) Volatile fatty acid production. In Quantitative Aspects of Ruminal Digestion and Metabolism, pp. 107-121 [JM Forbes and J France, editors]. Cambridge: University Press.

Huhtanen P \& Jaakkola S (1995) Intraruminal infusion technique for the estimation of ruminal VFA production. Annales de Zootechnie 44, Suppl., 168.

Huhtanen P, Miettinen H \& Ylinen M (1993) Effect of increasing ruminal butyrate on milk yield and blood constituents in dairy cows fed a grass silage-based diet. Journal of Dairy Science 76, $1114-1124$.

Hogan JP \& Weston RH (1967) The digestion of chopped and ground roughages by sheep. II. The digestion of nitrogen and some carbohydrates fractions in the stomach and intestines. Australian Journal of Agricultural Research 18, 803-819.

Institut National de la Recherche Agronomique (1989) Ruminant Nutrition Recommended Allowances and Feed Tables, [R Jarrige, editor]. Paris: INRA/John Libbey Eurotext.

Jouany JP \& Senaud J (1982) Influence des ciliés du rumen sur la digestion des différents glucides chez le mouton. I. Utilisation des glucides pariétaux (cellulose, hemicelluloses) et de l'amidon (Influence of rumen ciliate protozoa on digestion of difference carbohydrates in sheep. I. Utilisation of plant cell wall carbohydrates (cellulose, hemicellulose) and starch). Reproduction Nutrition Developement 22, 735-752.

Jouany JP (1982) Volatile fatty acids and alcohol determination in digestive contents, silage juices, bacterial cultures and anaerobic fermentor contents. Sciences des Aliments 2, 131-144.

Kristensen NB (2000) Technical note. Quantification of whole blood short-chain fatty acids by gas chromatographic determination of plasma 2-chloroethyl derivatives and correction for dilution space in erythrocytes. Acta Agriculturae Scandinavica 50, A231-A236

Kristensen NB \& Danfaer A (2000) The relationship between gastrointestinal production and portal absorption of short-chain fatty acids in ruminants. In Proceedings of the 15th Symposium Energy Metabolism in Animals, no. 103, pp. 277-280. Snekkersten, Denmark: EAAP.

Kristensen NB, Danfaer A, Tetens V \& Agergaard N (1996) Portal recovery of intraruminally infused short-chain fatty acids in sheep. Acta Agriculturae Scandinavica 46, A26-A38.

Leng RA \& Brett DJ (1966) Simultaneous measurements of the rates of production of acetic, propionic and butyric acids in the rumen of sheep on different diets and the correlation between production rates and concentrations of these acids in the rumen. British Journal of Nutrition 19, 541-552.

Leng RA \& Leonard GJ (1965) Measurement of the rates of production of acetic, propionic and butyric acids in the rumen of sheep. British Journal of Nutrition 19, 469-484.

Leng RA (1970) Formation and production of volatile fatty acids in the rumen. In Physiology of Digestion and Metabolism in the Ruminant, pp. 406-421 [AT Phillipson, editor]. Newcastle upon Tyne: Oriel Press.

Miettinen H \& Huhtanen P (1996) Effects of the ratio of ruminal propionate to butyrate on milk yield and blood metabolites in dairy cows. Journal of Dairy Science 79, 851-861.

Nozière P, Martin C, Rémond D, Kristensen NB, Bernard R \& Doreau M (2000) Effect of composition of ruminally-infused short-chain fatty acids on net fluxes of nutrients across portaldrained viscera in underfed ewes. British Journal of Nutrition 83, 521-531.

Oshio S, Tahata I, Kobayashi H \& Ami T (1977) Volatile fatty acids production in the rumen of young heifers given diets 
containing a large proportion of concentrate. Japanese Journal of Zootechnical Science 48, 545-553.

Peters JP, Shen RYW, Robinson JA \& Chester ST (1990) Disappearance and passage of propionic acid from the rumen of the beef steer. Journal of Animal Science 68, 3337-3349.

Rémond B, Brugère H, Poncet C \& Baumont R (1995) Le contenu du réticulo-rumen (The reticulo-rumen content). In Nutrition des Ruminants Domestiques: Ingestion et Digestion, pp. 253-298 [R Jarrige, Y Ruckebusch, C Demarquilly, MH Farce and M Journet, editors]. Paris: INRA.

Sharp WM, Johnson RR \& Owens FN (1982) Ruminal VFA production with steers fed whole or ground corn grain. Journal of Animal Science 55, 1505-1514.
Siciliano-Jones J \& Murphy MR (1989) Production of volatile fatty acids in the rumen and cecum-colon of steers as affected by forage: concentrate and forage physical form. Journal of Dairy Science 72, 485-492.

Sutton JD (1985) Digestion and absorption of energy substrates in the lactating cow. Journal of Dairy Science 68, 3376-3393.

Thomas PC \& Clapperton JL (1972) Significance to the host of changes in fermentation activity. Proceedings of Nutrition Society 31, 165-177.

Weller RA, Gray FV, Pilgrim AF \& Jones GB (1967) The rates of production of volatile fatty acids in the rumen. IV. Individual and total volatile fatty acids. Australian Journal of Agricultural Research 18, 107-118. 